\title{
Müşterilerin Restoran Seçimlerini Etkileyen Faktörler: İstanbul Örneği
}

\author{
Factors that Influence of Costumers' Restaurant Selection: The Case of Istanbul
}

\author{
Aslı ALBAYRAK* \\ * Yrd. Doç. Dr., T.C. İstanbul Arel Üniversitesi, Uygulamalı Bilimler Yüksekokulu, Tepekent Kampusu, 34537, İstanbul. \\ E-posta: aslialbayrak@arel.edu.tr
}

\author{
MAKALE BILGILERI \\ Makale işlem bilgileri: \\ Gönderilme tarihi: 5 Ağustos 2013 \\ Birinci değerlendirme: 5 Kasım 2013 \\ Kabul: 30 Aralık 2013 \\ Anahtar sözcükler: \\ Restoran, \\ Müşteri, \\ Müşteri seçim kriterleri, \\ İstanbul.
}

\section{ARTICLE INFO}

Article history:

Submitted: 5 August 2013

Resubmitted: 5 November 2013

Accepted: 30 December 2013

Key words:

Restaurant

Customer,

Customer selection criteria

Istanbul.

\begin{abstract}
ÖZ
Insanların sadece beslenme intiyaçlarını değil aynı zamanda birlikte olma, rahatlama, sosyalleșe gibi ihtiyaçarını da karşılayan restoran işletmeleri yoğun rekabet ortamında varlıklarını devam ettirebilmek ve ayakta kalabilmek için müşterilerin restoran seçimlerini etkileyen faktörleri göz önünde bulundurmak zorundadır. Müşterilerin restoran seçimlerini etkileyen pek çok faktör söz konusudur. Bu nedenle, bu çalıșma müșterilerin restoran seçimlerini etkileyen faktörleri belirlemek ve müșterilerin özellikleri ile restoran seçimlerini etkileyen faktörler arasında fark olup olmadığını ortaya koymak amacıyla yapılmıştır. Çalışma kapsamına İstanbul'da bulunan 1. sınıf restoranlar alınmıştır. Çalışma Nisan-Temmuz 2013 tarihleri arasında yürütülmüş, veriler anket tekniği ile toplanmış ve çalıșmaya 353 restoran müșterisi katılmıștır. Verilerin analizi için faktör analizi, Mann Whitney U ve Kruskal Wallis H testlerinden yararlanılmıștır. Çalıșma sonuçlarına göre müșterilerin restoran seçimlerinde sırasıyla "Restoran Özellikleri, Yiyecek ve içecekler, Hizmetler ile Parasal Değer" faktörlerinin önemli olduğu, restoran seçimlerini etkileyen faktörlerin gelir, öğrenim durumu ve restorana gitme sıklıkları açısından farklılık gösterdiği bulunmuștur.
\end{abstract}

\section{Giriş}

Günümüzde her türlü mal ve hizmeti üreten işletmeler için pazarlama faaliyetlerinin hareket noktası müşteridir. İşletmelerin müşterileri beklenti, ihtiyaç ve isteklerini analiz etmeden mal ya da hizmet üretmesi mümkün değildir. Çünkü günümüzde müşterilerin beklenti, ihtiyaç ve isteklerini karşılamaya yönelik, benzer amaca hizmet eden çok fazla sayıda mal ve hizmet üretilmekte ve bu ortamda rekabet avantajı sağlamak ve böylece hem kârlarını hem de imajlarını maksimize etmek isteyen işletmeler müşterilerini anlamaya çalışmak zorunda kalmaktadır. Bu nedenle hangi tür mal ya da hizmet söz konusu olursa olsun işletmeler müşte- rilerinin tercihleri ile ilgili düşünce ve davranışlarını dikkate almak zorundadır. Söz konusu durum restoran işletmeleri için de geçerlidir. Sayıları her geçen gün artan restoran işletmeleri de hem müşterilerinin beklenti, ihtiyaç ve isteklerini karşılayabilmek hem de varlıklarını devam ettirmek ve yoğun rekabetin yaşandığı endüstri içerisinde ön plana çıabilmek için müşterilerin tercihlerini dikkate almak durumundadır.

Günümüzde tüketici gelirlerinde meydana gelen artış, artan iş yoğunluğu, çalışan kadın sayısındaki artış, zaman tasarrufu, ekonomiklik, yeni insanlarla tanışarak sosyalleşme, aile/arkadaşlarla birlikte olma, eğlenme, kolaylık, statü-prestij, yenilik ara- 
yışı ve evde yemek hazırlamaktan kaçınma gibi çeşitli faktörler nedeniyle daha fazla kişi restoranlarda yemek yemeyi tercih etmektedirler. Restoran, insanların rahat bir şekilde oturup yemek yemelerine olanak tanıyan, yemek servisi yapilan yerler olarak tanımlanmaktadır (Dash 2005: 5) ve restoran işletmelerinden oluşan restoran endüstrisi gittikçe büyüyen bir endüstri haline gelmiştir (Pedraja ve Yagüe 2001; Bareham 2004; Buchtal 2006). Restoran işletmeleri bir yandan bulunduğu bölgenin ekonomisine katkı sağlarken diğer yandan da turizm endüstrisinde çalışanların istihdamına da olanak tanımaktadır. Çünkü restoranlar konaklama, ulaşım, çekicilik ve aktivite faktörleri gibi turistik ürünün temelinde yer alan kritik faktörlerden biridir (Reynolds 1993: 48). İnsanlar gerek normal yaşantılarında gerekse seyahatleri sırasında içinde bulundukları yaşam dönemine ve sağlıklı olma isteklerine bağlı olarak pek çok yiyecek ve içeceğe ihtiyaç duymaktadır (Antonioli 1995). Dolayısıyla restoranlar turizm pazarlamasını etkileyen önemli bir faktördür (Antonioli 1999; Wood 2000).

Hizmet ekonomisi içerisinde önemli yeri olan restoran işletmeleri artan emek maliyeti, yüksek devir hızı, rekabet, yemek ve hizmet farklılığı ve fiyat tutarsızlığı gibi müşteriyi işletmeden uzaklaştırabilen durumlarla karşı karşıyadır (Lee vd. 2011; National Restaurant Association 2011). Bu nedenle restoran işletmelerinin daha fazla müşteri çekmek ya da müşterilerinin geri gelmelerini sağlamak amacıyla yoğun rekabet ortamında etkili hizmet sunmaları, yeni ürünler üretmeleri, müşterilerin zihninde farklılıklara neden olan ve onların restoran seçimlerini etkileyen değişkenleri tanımaları ve anlamaları gerekmektedir (Yüksel ve Yüksel 2002). Zira restoranların uzun süreli başarılı olarak varlıklarını devam ettirebilmeleri, müşterilerinin ihtiyaç ve isteklerini karşılayan ürünleri geliştirebilmelerine, konumlandırmalarına ve pazarlamalarına bağlıdır (Alonso vd. 2013: 549).

İlk etki aynı zamanda son etki olduğundan müşterilerin nerede yemek yiyeceklerine karar vermeden önce farklı elementlerden oluşan karar verme süreçlerini tahmin etmek restoran işletmeleri için önem taşımaktadır. Nitekim müşteriler sıklıkla fazla sayıda alternatifleri oldukları zaman bu alternatifler arasından seçim yapma konusunda kararsiz kalmaktadır (Myung vd. 2008: 120). Bu nedenle restoran işletmelerinin müşterilerin işletmeye bağlı kalmaları ve ödedikleri paranın karşılığını aldıklarını düşünmeleri için onlara unutulmaz bir deneyim sunmaları gerekmektedir (Alonso vd. 2013: 548). Diğer taraftan müşterilerin restoran tercihleri üzerine etki eden faktörlerin belirlenmesi, restoran yöneticilerinin daha doğru pazarlama stratejileri belirlemelerine (Auty 1992; Kim ve Geistfeld 2003) ve varlıklarını devam ettirmelerine olanak tanıyacaktır (Heskett vd. 1997; Chow vd. 2007).

Konuyla ilgili alanyazın incelendiğinde özellikle yurt dişında yapılan çalışmalarda müşterilerin restoran tercihlerinin belirlenmesine yönelik çeşitli çalışmalar yapılmış olmasına karşın ülkemizde konuya ilişkin çok az sayıda çalışma yapılmış olduğu görülmüştür. Bu nedenle, bu çalışma ile ülkemizde tüketicilerin restoran tercihleri üzerine etki eden faktörlerin belirlenmesinin alanyazına katkı sağlayacağı düşünülmektedir. Dolayısıyla bu çalışma, müşterilerin restoran seçimlerini etkileyen faktörler ile müşterilerin demografik özellikleri ile restoran seçimlerini etkileyen faktörler arasındaki ilişkiyi ortaya koymak ve elde edilen sonuçlar 1şığında restoran yöneticilerinin pazarlama stratejilerini geliştirmelerine olanak tanıyacak önerilerde bulunmak amacıyla yapılmıştır.

\section{ILGILI ALANYAZIN}

Müşterilerin restoran tercihleri çok çeşitli faktörlerden etkilenmektedir (Fitzsimmons ve Fitzsimmons 2000). Nitekim Pedraja ve Yagüe (2001: 316-317) işletmelerin faaliyetlerini başarılı bir şekilde gerçekleştirebilmeleri ve müşterilerin ihtiyaçlarını karşılayabilmeleri için müşterilerin restoran seçimlerinde hangi faktörlere dikkat ettiklerinin ve alternatifler arasından nasıl seçim yaptıklarının araştırılması gerektiğini belirtmiştir. Yazarlara göre bu faktörleri bilmek pazarlama ve operasyonel başarı açısından önem taşımaktadır. Günümüze değin müşterilerin restoran seçimlerini etkileyen faktörler ile ilgili yapılan çalışmalarda restoran işletmelerinin hedef pazarlarını tanıyabilmeleri ve uygun pazarlama stratejilerini geliştirebilmeleri için müşterilerin restoran seçimi ile ilgili davranışlarını bilmenin önemli olduğu belirtilmiştir. Bu çalışmaların tamamı müşterilerin restoran seçimlerini etkileyen faktörleri ve nihai olarak nerede yemek yiyeceklerine karar vermelerini etkileyen unsurları açıklamaktadir (Tablo 1). 
Tablo 1. Tüketicilerin Restoran Seçimlerini Etkileyen Faktörlere İlişkin Alanyazın

\begin{tabular}{ll}
\hline Restoran Seçimini Etkileyen Faktörler & Alanyazın \\
\hline Atmosfer & $\begin{array}{l}\text { Lewis (1981), Milliman (1982), Auty (1992), Baker vd. (1994), Kivela (1997), Clark ve Wood } \\
(1998), \text { Lahue (2000), Sharma ve Stafford (2000), Soriano (2001), Grossbart (2002), Erik ve }\end{array}$ \\
\hline Nir (2004), Rowe (2010), Özdemir (2010) & $\begin{array}{l}\text { Lewis (1981), Auty (1992), Kara vd., (1997), Kivela (1997), Clark } \\
\text { ve Wood (1998), Erik ve Nir (2004), Barta (2008), Choi vd. (2010), Özdemir (2010) }\end{array}$ \\
\hline Yemü/Yemek Çeşitliliği & $\begin{array}{l}\text { Lewis (1981), Auty (1992), Gregoire vd. (1995), Kivela, (1997), Qu (1997), Clark ve } \\
\text { Wood (1998), Soriano (2001), Barta (2008), Özdemir (2010) }\end{array}$ \\
\hline Fiyat & Lewis (1981), Auty (1992), Qu (1997), Kara vd., (1997), Kivela (1997), Clark ve Wood (1998), \\
\hline Bölge & Pedraja ve Yagüe (2001), Soriano (2001), Arıker (2012) \\
\hline Temizlik & Qu (1997), Kivela (1997), Cullen (2004), Buchtal (2006), Knutson vd. (2006), Özdemir (2010), \\
\hline Malıker (2012) \\
\hline Kalabalık & Gregoire vd.(1995), Kara vd., (1997), Kivela (1997), Cullen (2004) \\
\hline Çalışanların Davranışları & Qu (1997), Fu ve Parks (2001), Soriano (2001) \\
\hline Servis Hızı & Tse vd. (2002), Erik ve Nir (2004) \\
\hline Besin İçeriği & Gregoire vd. (1995), Kivela (1997) \\
\hline Rahatık & Clark ve Wood (1998), Raab vd. (2009) \\
\hline Çocuk Opsiyonu & Wootan ve Osborn (2006) \\
\hline Iş̧letmenin Çalışma Saatleri & Kara vd., (1997), Kivela (1997) \\
\hline Işletme İmajı & Kara vd., (1997), Arıker (2012) \\
\hline Ödenilen Paranın Karşığı vd., (1997) \\
\hline
\end{tabular}

Tablo 1'de farklı araştırmacılar tarafından yapılan çalışma sonuçlarına göre müşterilerin restoran seçimlerini etkileyen faktörlere yer verilmiştir. Konuyla ilgili olarak alanyazında yer alan çalışmalardan elde edilen verilere göre müşterilerin restoran seçimlerini en fazla etkileyen faktörler "atmosfer, yemek/menü çeşitliliği, yemeklerin kaliteli/sağlıklı oluşu, fiyat, bölge, temizlik, mal ve hizmet kalitesi, kalabalık, çalışanların davranışları, servis hızı, yemeklerin besin içeriği, rahatlık, çocuk opsiyonu, işletmenin çalışma saatleri, işletme imajı, ödenen paranın karşılığının alınması" olarak sıralanmıştır.

Müşterilerin restoran seçimlerini etkileyen faktörler bireyden bireye değişebildiği gibi aynı zamanda aynı bireyin seçim kriterleri farklı koşullar altında farklılık gösterebilmektedir (Boone ve Kurtz 2005). Örneğin bireyin restorana hangi amaçla gittiği (eğlenme, sosyalleşme, iş, kutlama, zaman tasarrufu vb.), birlikte gittiği kişiler (aile, eş, arkadaş vb.), restoranın türü (lüks restoran, kafe, hızlı yemek yenen işletmeler vb.) gibi faktörler de kişilerin seçimleri üzerinde etkili olabilmektedir (Auty 1992; Kivela vd. 1999a; O'Mahony ve Hall, 2007; Upadhyay vd. 2007). Diğer taraftan farklı müşterilerin, her bir seçim kriterine verdiği önem de farklı düzeyde olabilmektedir (Kivela vd. 1999b; Njite vd. 2008). Müşterilerin yemek yiyecekleri restorana karar vermelerini etkileyen faktörler ve bu faktörlerin önem derecesi müşterilerin kişilik, yaş, gelir, cinsiyet, medeni durum, aile yaşam dönemi gibi çeşitli faktörlerden de etkilenmektedir (Lewis 1981; Authy 1992; Gregoire vd. 1995; Kivela vd. 1999a; Yüksel ve Yüksel 2002; Kim vd. 2010; Harrington vd. 2011).

\section{YÖNTEM}

Müşterilerin restoran seçimlerini etkileyen faktörlerin incelenmesi, alan araştırmasıyla gerçekleştirilmiştir. Çalışma İstanbul ilinde bulunan Turizm İşletme Belgeli 1. sınıf restoran işletmelerinde NisanTemmuz 2013 tarihleri arasında yapılmıştır. 2011 
yılı Adrese Dayalı Kayıt Sistemi'ne göre İstanbul İli en fazla nüfusa sahip olan ildir ve farklı demografik özelliklere sahip olan kişilerden oluşmaktadır (TUIKK 2011). Dolayısıyla çalışma İstanbul ilinde gerçekleştirilmiştir. Diğer taraftan Turizm İşletme ve Yatırım Belgesine sahip yiyecek içecek işletmeleri en fazla İstanbul'da bulunmaktadır (Kültür ve Turizm Bakanlığı 2012). Bu nedenle İstanbul ilinde yapılacak bir çalışma sonucunda elde edilecek verilerin genellenebilme gücünün daha fazla olabileceği varsayılmıştır. Çalışmada 1 . sınıf restoran işletmelerinin çalışma kapsamına alınmasının nedeni ise bu restoranların müşteri tercihlerine daha fazla önem verdiklerinin ve bu restoranlara gelen müşterilerin de restoran seçiminde daha fazla seçici olduklarının varsayılmasıdır.

Kültür ve Turizm Bakanlı̆̆ 2012 yılı verilerine göre İstanbul ilinde 133 adet Turizm İşletme Belgeli, iki adet Turizm Yatırımı Belgeli 1. sınıf restoran işletmesi bulunmaktadır. Bu restoranların isimlerine ulaşabilmek amaciyla öncelikle İl Turizm Müdürlüğ̈̈'nden restoranların isimleri istenmiştir. İsimleri elde edilen restoranların web sayfalarından yararlanarak etnik restoranlar, özellikli restoranlar, gece kulübü olarak da hizmet sunan işletmeler belirlenmiş ve çalışma kapsamı dışında bırakılarak sadece Türk mutfağı, İtalyan mutfağı, Meksika mutfağı gibi birden fazla farklı mutfağa ait ürünlerle müşterilerine hizmet sunan, diğer bir ifade ile menüsünde farklı mutfaklara ait ürünlere yer veren restoranlar çalışma kapsamına alınmıştır. Özellikli restoranlar, etnik restoranlar ve gece kulüpleri olarak da hizmet sunan işletmelerin çalışma kapsamı dışında bırakılmasının nedeni bu restoranları tercih eden müşterilerin söz konusu işletmeleri eğlenmek, etnik bir bölgeye ya da mutfağa ait belirli yiyecekleri denemek amaciyla tercih etmiş olabileceklerinin varsayılmasıdır. Buna göre İstanbul ilinde farklı mutfakları ile müşterilerine hizmet sunan restoran sayisı 19 olarak belirlenmiştir. Öncelikle araştırmacı tarafından restoranlar telefonla aranarak yöneticileri ile görüşülmüş, çalışmanın içeriği aktarılmış ve çalışmaya katılmak isteyip istemedikleri sorulmuştur. 19 restorandan beş tanesi çalışmaya katılmayı kabul etmemiş ve böylece çalışma kapsamına 14 restoran işletmesi alınmıştır.

İstanbul'da 1. sınıf restoranları tercih eden müşterilerin sayısı tam olarak bilinmediğinden Yazıcıoğ- lu ve Erdoğan (2004: 49-50) tarafından d=+- 0,05 örnekleme hatası ve $\mathrm{p}=0,05, \mathrm{q}=0,05$ güven aralığında evrenin 1 milyon ile 100 milyon olması durumunda örneklem büyüklüğünün 384 olması gerektiğinin belirtilmiş olduğu Örneklem Büyüklüğü Tablosundan yararlanılmıştır. Bu verilerden hareketle örneklem büyüklüğü 384 olarak belirlenmiş ve örnekleme alınacak bireyler kolayda örnekleme yöntemi ile seçilmiştir. Veri toplama aracı olarak anket tekniği kullanılmıştır. Anket formu iki bölümden oluşmaktadır. Birinci bölümde müşterilerin yaş, cinsiyet, öğrenim durumları, gelirleri gibi tanımlayıcı özelliklerini belirlemeyi sağlayacak sorular ile müşterilerin restorana gitme sıklıkları, nedenleri ve restoranlara birlikte gittikleri kişileri belirlemek amacıyla sorulan sorular yer almaktadır. İkinci bölümde ise müşterilerin restoran seçimlerini belirlemeye yönelik 23 maddeden oluşan bir ölçek kullanılmıştır. Ölçeğin oluşturulmasında Cullen (2004), Choi ve Zhau (2010), Harrington vd. (2011) ve Alonso vd. (2013) tarafından daha önce yapılmış olan çalışmalardan yararlanılmıştır. Katılımcılardan bu bölümde yer alan soruları 1=kesinlikle katıliyorum, $5=$ =kesinlikle katılmıyorum şeklinde beş aralıklı ölçekle değerlendirmeleri istenmiştir. Anket formunun hazırlanmasının ardından anketteki aksayan ve eksik olan kısımlar ile anketin ikinci bölümünde yer alan ifadelerin tam olarak anlaşlıp anlaşılmadığının, sorulara tam ve anlaşılır şekilde cevap verilip verilmediğinin ve anketin güvenilirliğinin tespiti için çalışma kapsamına alınan restoran işletmelerinden birinde 30 müşteriyle pilot çalışma yapılmıştır. Pilot çalışma sonucunda katılımcıların önerileri doğrultusunda anlaşılmasında güçlük çekilen bazı ifadeler düzeltilmiştir (örneğin, tamamlayıcı hizmetlerin varlığı ifadesi yemek dişı hizmetlerin varlı̆̆ 1 olarak değiştirilmiştir). Pilot çalı̧̧ma sonuçları değerlendirildiğinde anket formunun genel güvenilirlik testi sonucunda Cronbach Alpha değeri ,802 olarak saptanmıştır. Bu sonuç, anket formunun genel iç uyumunun kabul edilebilir düzeyin üzerinde olduğunu göstermiştir (Nunnally 1978). Bu nedenle anket formları çoğaltılarak çalışmanın uygulama aşamasına geçilmiş̧ir. Verilerin toplanması aşamasında, Nisan-Temmuz 2013 tarihleri arasında restoran yöneticilerinin önerisiyle yemeklerini tamamlayan müşterilere ankete katılmak isteyip istemedikleri sorulmuş, katılmak isteyenlere anket verilerek kendilerinin doldurması istenmiştir ve tamamlanan anket formları yine 
işletme yöneticilerine teslim edilmiştir, anketler daha sonra araştırmacı tarafından işletme yöneticilerinden alınmıştır. Verilerin işlenmesi sırasında 31 anketin eksik ya da yanlış doldurulduğu tespit edilmiş ancak işletmelere ve müşterilere yeniden ulaşmanın zaman maliyeti nedeniyle bu anket formları çalışma kapsamı dışında bırakılmış ve 353 anket değerlendirmeye alınmıştır. Elde edilen veriler SPSS 15.0 (Statistical Package for the Social Sciences) paket programıyla değerlendirilmiştir.

Çalışmaya katılan müşterilerden elde edilen verilere ilişkin öncelikle güvenilirlik testi yapılmış ve test sonucunda Cronbach Alpha değeri ,784 olarak saptanmıştır. Bu sonuç, çalışma sonucunda elde edilen verilerin iç uyumunun kabul edilebilir düzeyin üzerinde olduğunu ve ilgili analizlerin yapılabileceğini göstermiştir. Çalışma kapsamına alınan katılımcıların özellikleri ve restorana gitme davranışlarına ilişkin tanımlayıcı sorularla ilgili verilerin analizinde yüzde ve frekans dağılımlarından yararlanılmıştır. İkinci kısımda ise müşterilerin restoran tercihlerini etkileyen faktörlerin belirlenebilmesi için faktör analizi uygulanmıştır. Müşterilerin restoran seçimlerini etkileyen faktörlerin belirlenmesinde faktör analizinin kullanılmasının nedeni, daha önce yapılmış çalışmalardan yararlanilarak oluşturulan ve 23 maddeden oluşan ifadeler arasındaki ilişkiyi anlamak ve müşterilerin restoran seçimlerini etkileyen faktörleri daha az sayıdaki temel boyuta indirgemektir. Böylece müşterilerin restoran seçimlerini etkileyen fazla sayıdaki değişkenden oluşan veriler daha az sayıda yeniden oluşturulmuş değişkenler olarak ifade edilmiştir. 23 maddeden oluşan ölçeğe ilişkin yapılan analiz sonucunda dört ifade faktör yükleri açısından 0,50'den küçük değer aldığı için bu faktörlerin faktör analizine uygun olmadığ 1 anlaşılmış ve analizden çıkartılarak kalan 19 değişkenle analiz tekrar yapılmıştır. Daha sonra elde edilen faktörlerin müşterilerin bazı demografik özelliklerine göre farklılık gösterip göstermediklerini incelemek için veriler normal dağ Whitney U ve Kruskal Wallis H analizlerinden yararlanılmıştır. Değerlendirilen tüm veriler \%95 güven aralığında incelenmiştir. Çalışmada test edilecek hipotezler şu şekilde belirlenmiştir:

H1: Farkl yaş grubundaki müşterilerin restoran seçimlerini etkileyen faktörler arasında anlamlı bir fark vardir.
H2: Farklı öğrenim durumundaki müşterilerin restoran seçimlerini etkileyen faktörler arasında anlamlı bir fark vardir.

H3: Farklı gelir düzeyindeki müşterilerin restoran seçimlerini etkileyen faktörler arasında anlamlı bir fark vardir.

H4: Restorana gitme sıklı̆̆ farklı olan müşterilerin restoran seçimlerini etkileyen faktörler arasında anlamlı bir fark vardir.

H5: Kadın ve erkek müşterilerin restoran seçimlerini etkileyen faktörler arasında anlamlı bir fark vardır.

\section{BULGULAR}

Anket çalışması sonucunda elde edilen verilerin değerlendirilmesinde öncelikle katılımcıların demografik özellikleri ve restorana gitme davranışlarına ilişkin bilgiler frekans ve yüzde tabloları ile ifade edilmiş, daha sonra müşterilerin restoran seçimleri ile ilgili ifadeler için faktör analizi uygulanmış, son olarak elde edilen faktörlerin müşterilerin özelliklerine göre farklılık gösterip göstermediği incelenmiştir.

Tablo 2'de katılımcıların demografik özellikleri ile restorana gitme davranışlarına göre dağılımları yer almaktadır. Katılımcıların üçte ikilik kısmından fazlasinın $(\% 68,8)$ kadın ve $\% 31,2$ 'sinin erkek olduğu görülmektedir. Çalışmaya katılan müşterilerin yarıdan fazlası $(\% 55,5) 30-39$ yaşındayken bunu \%28,9 oraniyla 20-29 yaş arasında olanlar, \%13,9 oraniyla 40-49 yaş arasında olanlar ve \%1,7 oranıyla 50-59 yaş arasında olanlar takip etmektedir. Katılımcılar öğrenim durumları açısından incelendiğinde yine yarıdan fazlasının (\%51,9) üniversite, $\% 38,8^{\prime}$ inin orta öğretim, \%6,8'inin ilköğretim ve $\% 2,5^{\prime}$ inin lisansüstü mezunu oldukları görülmüştür. Katılımcıların gelirleri açısından ise orta üst düzey gelir düzeyinde oldukları söylenebilir. Zira kat1lımcların \%51,8'i 3.001-6.000TL ve \%42,8'i 6.001 TL üzerinde gelire sahip olduklarını belirtmişlerdir. Diğer taraftan yapılan analizde katılımcıların yarıdan fazlasının $(\% 54,4)$ ayda dört-beş kez, \%28,8'inin ayda beş kereden fazla, \%13,3'ünün ayda iki-üç kez ve \%6,5'inin ayda bir kez restorana gittikleri ve restorana giderken katılımcıların yarıya yakınının $(\% 47,9)$ arkadaşları, $\% 39,4^{\prime}$ ünün aile üyeleri ve \%12,6'sının yalnız olarak restorana gittikleri saptanmıştır. Katılımcılar restorana gitme nedenleri açısından incelendiğinde en fazla 
Tablo 2. Katılımcıların Demografik Özellikleri ve Restorana Gitme Davranışlarına Göre Dağılımları

\begin{tabular}{|c|c|c|c|c|c|}
\hline & $f$ & $\%$ & & $f$ & $\%$ \\
\hline Cinsiyet & & & Yaş & & \\
\hline Erkek & 110 & 31,2 & $20-29$ & 102 & 28,9 \\
\hline Kadın & 243 & 68,8 & $30-39$ & 196 & 55,5 \\
\hline Öğrenim Durumu & & & $40-49$ & 49 & 13,9 \\
\hline İlköğretim & 24 & 6,8 & $50-59$ & 6 & 1,7 \\
\hline Ortaöğrenim & 137 & 38,8 & Aylık Gelir & & \\
\hline Üniversite & 183 & 51,9 & $<3.000$ & 19 & 5,4 \\
\hline Lisansüstü & 9 & 2,5 & $3.001-6.000$ & 183 & 51,8 \\
\hline Restoranda Yemek Yeme Sıklığı & & & $6.001+$ & 151 & 42,8 \\
\hline Ayda 1 & 23 & 6,5 & Restorana Gitme Sebebi & & \\
\hline Ayda 2-3 & 47 & 13,3 & Kolaylık & 52 & 5,1 \\
\hline Ayda 4-5 & 192 & 54,4 & Aile, arkadaş vb. ile birlikte olma & 288 & 28,4 \\
\hline Ayda $5+$ & 91 & 28,8 & Sosyalleşme & 63 & 6,2 \\
\hline Birlikte Restorana Gidilen Kişi & & & Eğlenme & 70 & 6,9 \\
\hline Yalnız & 91 & 12,6 & Zaman Tasarrufu & 93 & 9,1 \\
\hline Aile Üyeleri & 284 & 39,4 & Ekonomik Olması & 124 & 12,2 \\
\hline \multirow[t]{3}{*}{ Arkadaşlar } & 345 & 47,9 & Statü-Prestij & 61 & 6,0 \\
\hline & & & Farklılık & 109 & 10,7 \\
\hline & & & Özel Nedenler (iş-kutlama vb.) & 157 & 15,4 \\
\hline
\end{tabular}

$(\% 28,4)$ aile, arkadaş ve tanıdıklarla birlikte olmak amacıyla restorana gittikleri, bunu iş, kutlama gibi özel nedenlerle gidenlerin $(\% 15,4)$, ekonomik olması nedeniyle gidenlerin $(\% 12,2)$, farklılık olması nedeniyle gidenlerin $(10,7)$, zaman tasarrufu nedeniyle gidenlerin $(\% 9,1)$, eğlenme nedeniyle gidenlerin $(\% 6,9)$, sosyalleşme nedeniyle gidenlerin $(\% 6,2)$, statü-prestij nedeniyle gidenlerin $(\% 6,0)$ ve kolaylık sağlaması nedeniyle gidenlerin $(\% 5,1)$ takip ettiği bulunmuştur.

Tanımlayıcı verilerin analizinden sonra müşterilerin restoran seçimiyle ilgili ölçeğin analizi için temel bileşenler faktör analizi kullanılmıştır. Toplam 19 ifadeden oluşan analizin sonuçlarına göre araştırmada kullanılan ifadeler faktör analizinin yapılabilmesi için uygun olma koşulunu sağlamaktadır ( $\mathrm{KMO}=0,87)$. Bu değer değişkenin faktör analizine uygun olduğunu göstermektedir (Sipahi vd. 2008: 80).

Faktör analizi sonucunda faktör yükleri 0,50'den ve özdeğerleri 1'den büyük olan dört faktör elde edilmiştir. Bu faktörler "Restoran Özellikleri, Yiyecek ve İçecekler, Hizmetler ve Parasal Değer" olarak isimlendirilmiştir (Tablo 3). Elde edilen dört faktörlü yapı toplam varyansın \%61,6'sını açıklamaktadir. Restoran Özellikleri faktörü toplam varyansın \%33,20'sini, Yiyecek ve İçecekler faktörü \%13,25'ini, Hizmetler faktörü \%9,5'ini ve Parasal Değer faktörü \%5,59'unu açıklamaktadır. Bu sonuçlardan hareketle tüketicilerin restoran seçimlerinde Restoran Özelliklerinin birinci dereceden, Yiyecek ve İçeceklerin ikinci dereceden, Hizmetlerin üçüncü dereceden ve Parasal Değerin dördüncü dereceden önem verilen faktörler olduğu görülmüştür.

Müşterilerin restoran seçimlerini birinci dereceden etkileyen Restoran Özellikleri faktöründe en yüksek faktör yükünü atmosfer ifadesi alırken bunu restorana duyulan güven ve restoranın bilinirlik, temizlik, bölge, rahatlık, kalabalık olmama ve çalışma saatleri takip etmektedir. Nitekim alanyazında yer alan bazı çalışmaların sonuçları bu so- 
Tablo 3. Faktör Analizi Sonuçları

\begin{tabular}{|c|c|c|c|c|c|c|}
\hline \multirow[t]{2}{*}{ Faktör Grupları } & \multicolumn{4}{|c|}{ Faktör Yükleri } & \multirow[t]{2}{*}{ A.O } & \multirow[t]{2}{*}{ SS. } \\
\hline & 1 & 2 & 3 & 4 & & \\
\hline \multicolumn{7}{|l|}{ Faktör 1: Restoran Özellikleri } \\
\hline Restoran Atmosferi & ,856 & & & & 1,84 & 0,88 \\
\hline Güven & ,826 & & & & 1,95 & 0,93 \\
\hline Restoranın Bilinirliği & ,738 & & & & 1,89 & 0,90 \\
\hline Temizlik & ,706 & & & & 2,13 & 1,01 \\
\hline Bölge & ,669 & & & & 1,37 & 0,66 \\
\hline Rahatlık & 671 & & & & 2,30 & 1,10 \\
\hline Kalabalık & ,638 & & & & 1,96 & 0,94 \\
\hline Çalışma Saatleri &, 614 & & & & 1,91 & 0,91 \\
\hline \multicolumn{7}{|l|}{ Faktör 2: Yiyecek ve İçecekler } \\
\hline Yemeklerin Kalitesi & & ,827 & & & 2,68 & 1,24 \\
\hline Yemek (Menü) Çeşitliliği & & ,797 & & & 2,64 & 1,22 \\
\hline Farklı Mutfakların Varlığı & & 689 & & & 2,40 & 1,11 \\
\hline Yemeklerin Besin Değeri & &, 524 & & & 2,21 & 1,02 \\
\hline \multicolumn{7}{|l|}{ Faktör 3: Hizmetler } \\
\hline Çalışanların Davranışları & & &, 740 & & 1,72 & 0,83 \\
\hline Servis Hızı & & & ,735 & & 1,81 & 0,88 \\
\hline Çalışanların Yetkinliği & & & ,730 & & 1,86 & 0,90 \\
\hline Yiyecek Dışı Hizmetlerin Varlığı & & &, 705 & & 1,89 & 0,92 \\
\hline \multicolumn{7}{|l|}{ Faktör 4: Parasal Değer } \\
\hline Fiyat & & & &, 757 & 2,29 & 1,04 \\
\hline Ödenen Paranın Karşılığı & & & &, 657 & 2,15 & 0,98 \\
\hline Kart Kullanabilme & & & & ,610 & 1,67 & 0,76 \\
\hline Faktörlerin Aritmetik Ortalaması & 1,92 & 2,48 & 1,82 & 2,04 & & \\
\hline Özdeğer & 6,746 & 2,520 & 1,909 & 1,121 & & \\
\hline Tanımlanan Fark Yüzdesi & 33,20 & 13,25 & 9,54 & 5,59 & & \\
\hline Güvenilirlik Katsayısı & 0,88 & 0,75 & 0,81 & 0,70 & & \\
\hline
\end{tabular}

$\mathrm{p}<, 05$

nuçları destekler niteliktedir. Örneğin Erik ve Nir (2004) çalışmalarında restoran seçiminde en önemli faktörün atmosfer olduğunu belirtirken Cullen (2004) işletmenin bilinirliğinin, Gregoire vd. (1995), Kivela (1997) ve Kara vd. (1997) temizliğin, Qu (1997), Buchtal (2006) ve Knutson vd. (2006) bölgenin, Kara vd. (1997) rahatlığın, Tse vd. (2002) ve Erik ve Nir (2004) kalabalığın ve Kara vd. (1997) çalışma saatlerinin önemli olduğunu belirtmişlerdir.

Restoran seçimini etkileyen ikinci dereceden önemli faktör ise Yiyecek ve İçecekler'dir ve en fazla faktör yüklerini yiyeceklerin kalitesi ve menü çeşitliliği almıştır. Müşterilerin restoran seçimleri ile ilgili yapılan pek çok çalışma bu sonuçları destekler niteliktedir (Auty 1992; Kivela 1997; Kara vd. 1997; Qu 1997; Clark ve Wood 1998; Lewis Soriano 2001; Choi vd. 2010). Üçüncü dereceden önemli olan Hizmetler faktöründe çalışanların davranışları, servis hızı en yüksek faktör yüklerine sahiptirler. Nitekim Gregoire vd. (1995), Kivela (1997) çalışmalarında çalışanların davranışlarının, Clark ve Wood (1998) ile Raab vd. de (2009) servis hızının müşterilerin restoran seçimlerinde etkili olduğunu belirtmişlerdir. Bu sonuçlar çalışma sonucunda elde edilen verileri destekler niteliktedir. Dördüncü dereceden önemli olan Parasal Değer faktöründe ise fiyat ve ödenen paranın karşılığını alma en yüksek faktör yükünü almış, alanyazında yer alan bazı çalışmalarda da benzer sonuçlar elde edilmiştir (Qu 1997; Kara vd. 1997; Kivela 1997; Clark ve Wood 1998; Pedraja ve Yagüe 2001; Soriano 2001; Raab vd. 2009).

Tablo 4'te müşterilerin restoran seçimlerini etkileyen faktörler üzerinde yaş, öğrenim, gelir ve res- 


\begin{tabular}{lcccrr}
\hline & \multicolumn{3}{c}{ Faktörler } \\
\hline & & $\begin{array}{c}\text { Restoran } \\
\text { Özellikleri }\end{array}$ & $\begin{array}{c}\text { Yiyecek } \\
\text { ve lçecekler }\end{array}$ & Hizmetler & $\begin{array}{r}\text { Parasal } \\
\text { Değer }\end{array}$ \\
\hline Yaş & Ki-kare &, 886 &, 753 & 2,928 & 1,836 \\
\hline Öğrenim & Pearson &, 612 &, 735 &, 053 &, 376 \\
\hline Gelir & Ki-kare & 4,743 & 9,672 & 2,646 & 17,025 \\
\hline & Pearson &, 313 &, $043^{*}$ &, 752 &, 085 \\
\hline Restorana Gitme Sıklığı & Ki-kare & 3,515 & 3,122 & 17,983 & 8,320 \\
\hline & Pearson &, 317 &, 350 &, $001^{*}$ & 0,102 \\
\hline & Ki-kare & 13,875 & 3,132 & 9,423 & 6,907 \\
\hline
\end{tabular}

${ }^{*} \mathrm{p}<, 05$

torana gitme sıklıklarının etkili olup olmadığı incelenmiştir. Yaş değişkeni için yapılan analizde dört faktör için elde edilen değerlerin , 05 'ten büyük olduğu görülmüştür ve H1 reddedilmiştir. Buradan hareketle yaşın restoran seçiminde belirleyici bir faktör olmadığı sonucuna varılmaktadır. Tüketicilerin öğrenim durumları ile müşterilerin restoran seçimlerini etkileyen faktörler arasındaki ilişki incelendiğinde anlamlı bir farklılığın olduğu gözlemlenmiş ve $\mathrm{H} 2$ kabul edilmiştir. Başka bir ifade ile farklı öğrenim düzeyindeki müşteriler için restoran işletmelerinde sunulan yiyecek ve içecekler restoran seçimlerinde farklı derecede öneme sahiptir.

Müşterilerin gelirleri ile restoran seçimlerini etkileyen faktörler arasındaki ilişki incelendiğinde Hizmetler faktöründe anlamlı bir farklılığın olduğu görülmüştür. Dolayısıyla H3 kabul edilmiştir. Diğer bir ifade ile farklı gelir düzeyindeki müşteriler için restoran seçimlerinde restoranlarda sunulan Hizmetlere verilen önem farklılık göstermektedir. Yapılan analiz sonucunda müşterilerin restorana gitme sıklığı ise Restoran Özellikleri ve Hizmetler faktörlerinin algılanmasında farklılık yaratmıştır. Bu nedenle H4 kabul edilmiştir. Diğer bir ifade ile müşterilerin restorana gitme sıklıkları farklılaştıkça restoran seçimlerinde Restoran Özellikleri ve Hizmetler faktörleri etkili olmakta; Yiyecek ve İçecekler ile Parasal Değer faktörleri etkili olmamaktadir.

Tablo 5'te katılımcıların restoran seçimlerini etkileyen faktörlerin cinsiyete göre farklılaşma durumu yer almaktadır. Buna göre cinsiyet ile müşterilerin restoran seçimlerini etkileyen faktörler arasında anlamlı bir fark yoktur. Bu nedenle H5 reddedilmiştir. Diğer bir ifade ile müşterilerin cinsiyetleri restoran seçimlerini etkileyen faktörlerde farklılaşmaya neden olmamaktadır.

\section{SONUÇ VE ÖNERILER}

Günümüz rekabet ortamında restoran işletmeleri mevcut durumlarını devam ettirebilmek, kendilerini yenilemek ve rekabet ortamında ön plana çıkabilmek için müşteri tercihlerini, ihtiyaç ve isteklerini bilmek ve bu tercihler doğrultusunda mal ve hizmet sunumlarına devam etmek zorundadırlar. Diğer taraftan müşterilerin yaşam standartlarında

Tablo 5. Mann Whitney U Testi Sonuçları

\begin{tabular}{lcccrrr}
\hline \multicolumn{7}{c}{ Faktörler } \\
\hline Cinsiyet & Restoran Özellikleri & Yiyecek \& Içecekler & Hizmetler & Parasal Değer \\
\hline & $\mathrm{Z}$ &,- 354 &,- 644 &,- 219 & $-1,233$ \\
\hline $\mathrm{p}<, 05$ & $\mathrm{P}$ &, 743 &, 381 &, 822 &, 213 \\
\hline
\end{tabular}

$\mathrm{p}<, 05$ 
meydana gelen değişmeler, gelir ve öğrenim düzeylerindeki artış gibi kişisel özellikleri ve yaşam standardındaki artış, müşterilerin tercihlerinde de farklılaşmalara neden olmaktadır. Bu nedenle restoran işletmelerinin başarılı pazarlama stratejileri geliştirebilmeleri için müşterilerin restoran tercihleri etkileyen faktörler hakkında bilgi sahibi olmaları önem taşımaktadır.

Müşterilerin restoran seçimlerini etkileyen faktörleri ve bu faktörlerin müşterilerin özelliklerine göre farklılaşıp farklılaşmadığını ortaya koymak amacıyla yapilan bu çalışmaya katılan müşteriler içinde genç, yükseköğrenim görmüş, yüksek gelirli ve kadın müşteriler oransal olarak diğer müşteri gruplarından daha fazladır. Çalışmaya katılan müşterilerin büyük bir bölümü genellikle $(\% 87,3)$ aile üyeleri ve arkadaşlarıyla birlikte ayda en az dört kez $(\% 80,2)$ ve en fazla aile, arkadaş ve tanıdıklarla birlikte olmak ve iş, kutlama gibi özel nedenlerle restoranlara gitmektedirler. Bu sonuçlardan hareketle, restoran yöneticilerine uyumluluk yönetimi çerçevesinde işletmelerinin bir kısmını büyük grupların bir arada oturup yemek yiyebilecekleri aynı zamanda birlikte hoşça zaman geçirebilecekleri türde alanlar olarak planlamaları önerilebilir. Bununla birlikte literatürde yer alan bazı çalışmalarda (Lin, 2004) müşterilerin restoranda kendilerine ayrılan bölümün diğer gruplardan uzak olmasını tercih ettikleri belirtilmiştir. Bu nedenle restoran yöneticilerine yakınları, arkadaşları ve tanıdıkları ile birlikte yemek yemek ve aynı zamanda belirli bir süreyi birlikte geçirmek isteyen müşterileri için U şeklinde loca oturma düzeninde masalar düzenlemeleri önerilebilir. Bu düzen müşterilerin daha samimi bir ortamda yemek yemelerine olanak sağlayacaktır. Aynı zamanda bu oturma düzeni müşterilerin restoran içerisindeki trafikten uzak kalmalarına ve diğer misafirler ya da çalışanlarla çarpışmaların önlenmesine ve dolayısıyla müşterilerin rahat etmelerine ve memnun olmalarina da olanak sağlayacaktır.

Müşterilerin restoran seçimlerini etkileyen en önemli faktör "Restoran Özellikleri" iken bunu "Yiyecek ve İçecekler", "Hizmetler" ve "Parasal Değer" faktörleri takip etmektedir. Restoranın atmosferi, bilinirliği (imajı), temizliği, bulunduğu bölge, müşterilere rahat bir ortamda deneyim sunması ve kalabalık olmaması müşteriler için restoran seçimlerini etkileyen en önemli nedenlerdir.
Nitekim Bitner (1992: 67) atmosferin müşteri tercihlerinde ve yaşadıkları tecrübe üzerinde son derece önemli olduğunu belirtirken bazı çalışmalarda da (Turley ve Milliman 2000; Sulek ve Hensley 2004; Han ve Ryu 2009; Kim ve Moon 2009) restoran atmosferinin müşterilerin restoranlarla ilgili tercih yapmaları gerektiğinde belirleyici kriter olduğunu, müşterilerin genel memnuniyetlerini ve işletmeye bağlılıklarını etkilediğini belirtmişlerdir. Bu sonuçlar atmosferin müşteriler için son derece önemli olduğunu ve işletmeye tekrar gelme niyetlerini etkilediğini göstermiştir. Dolayısıyla müşteri memnuniyetini arttırmak ve rekabet ortamında ön planda yer almak isteyen restoran işletmelerinin, müşterilerin restoranda geçirecekleri zamanın kalitesini arttırmak ve işletmeye geri gelmelerini sağlamak amacıyla rahatsız olmayacakları bir atmosfer yaratmaları gerekmektedir. Bunun için restoran yöneticilerine müşterileri için uygun olacak bir havalandırma ve klima sistemleri oluşturmaları, işletme içerisinde istenmeyen kokuları ve özellikle yemek kokusunu engellemeleri, işletme içerisindeki müzik ses düzeyini müşterileri rahatsız etmeyecek düzeyde tutmaları ve mümkün olduğunca sözsüz müzikleri tercih etmeleri, durgun ve görmeyi engellemeyen bir ışıklandırma kullanmaları, işletme mimarisinin işletmenin genel havasını yansıtacak şeklide düzenlenmeleri ve işletme içerisinde kullanılan mobilyaları rahat oturmayı ve yemek yemeyi sağlayacak şekilde seçmeleri önerilebilir.

"Yiyecek ve İçecekler" farklı öğrenim durumundaki müşteriler için restoran seçiminde daha fazla öneme sahip olan bir faktördür. Diğer bir ifade ile öğrenim düzeyi farklı olan müşterilerin restoran tercihlerinde restoranda sunulan yiyecek ve içeceklerin kalitesi, menü çeşitliliği, farklı mutfakların varlığ oynamaktadır. Müşterilerin ihtiyaç ve isteklerini karşılayarak onları daha fazla memnun edebilmek için işletmelere menü kartlarına ve web sayfalarına kullandıkları malzemelerin hangi kalite standartlarında olduğunu ifade eden ibareler koymaları, müşterilerin önerilerini alarak menülerini genişletmeleri, farklı mutfaklara ait önemli yemekleri menüye eklemeleri ve menü kartlarında yer alan tanımlayıcı yazılara yemeklerin kalori değerlerini eklemeleri önerilebilir.

"Hizmetler" faktörü ise farklı gelir düzeyindeki ve restoranlara sıklıkla giden müşteriler için 
restoran seçiminde daha fazla öneme sahiptir. $\mathrm{Bu}$ müşteriler için restoranda çalışanların davranışları, servis hızı, çalışanların yetkinliği ve yemek d1şındaki hizmetlerin varlı̆̆ özellikleri, restoran seçimlerinde daha fazla etkilidir. Diğer taraftan çalışanların davranışları, çalışanların bilgi düzeylerini ifade eden yetkinlikleri, servis hızı ve yemek dışı hizmetler gelir düzeyi ve restorana gitme sıklığ1 arttıkça daha fazla önemli hale gelmektedir. Bu sonuçlar, restoran işletmelerinin müşterileri için yaratacakları olumlu atmosferin yanında sunacakları hizmetlerle de memnuniyet düzeylerini ve tekrar gelme isteklerini arttırabileceğini göstermektedir. Buradan hareketle restoran işletmelerine müşteri memnuniyetini arttırabilmek amacıyla çalışanları periyodik olarak müşteri ilişkileri konusunda eğitmeleri, servisin hızlı şekilde sağlanabilmesi için işletmenin sunduğu yiyecek-içecek türlerinin gerektiği servis türlerini bilen elemanlar almaları ve/veya çalışanların servis konusunda eğitilmesi, diğer taraftan müşterilere vale hizmeti, ücretsiz otopark hizmeti, çocuk oyun odası hizmeti gibi yemek d1şındaki ihtiyaçlarını karşılayacak hizmetler sunmaları önerilebilir.

Dikkat çekici diğer bir sonuç ise fiyat, ödenen paranın karşılığının alınması ve kredi kartı kullanabilme özelliklerini ifade eden "Parasal Değer" faktörünün çalışmanın yapıldığ grup için restoran seçimini etkileyen bir faktör olarak belirtilmemiş olmasıdır. Bu durum müşterilerin özellikleri ne kadar farklı olursa olsun tamamının restoran seçiminden önce restoranda yaşayacak deneyimin daha sonra yiyecek ve içecekler ile hizmetlerin restoran seçimlerini etkilediğini, bunun karşıllı̆ı̆nda ödemeleri gereken parasal değerin restoran seçimleri üzerinde etkili olmadığını göstermektedir.

Çalışmanın yöntem kısmında belirtildiği üzere bu çalışma sadece İstanbul ilinde bulunan sınırlı sayıdaki 1. sınıf restoran işletmelerinde, 353 kişi ile gerçekleştirilmiştir ve bu durum çalışmaya ilişkin en önemli kısıttır. Dolayısıyla çalışma sonucunda elde edilen veriler şüphesiz geneli tam olarak yansitmamaktadır. Bu nedenle önümüzdeki zamanlarda çalışmada kullanılan daha geniş bir örneklemle ölçek kullanılarak daha fazla sayıda farklı tipteki restoranlarda benzer bir çalışma yapılabileceği gibi farklı özellikteki restoranlara gelen müşterilerin seçim kriterlerindeki farklılaşma karşılaştırılabilir.

\section{KAYNAKÇA}

Alonso, D. A., O'Neill, M., Liu, Y. ve O'Shea, M. (2013). Factors Driving Consumer Restaurant Choice: An Exploratory Study from the Southeastern United States, Journal of Hospitality Marketing \& Management, 22 (5): 547-567.

Antonioli, C. M. (1995). Enoturismo: Caratteristiche Della Domanda, Strategie Dell' Offertae Aspetti Territoriali E Ambientali. Milano: Franco Angeli.

Antonioli, C. M. (1999). Strade Del Vino Ed Enoturisms. Distretti Turistici E Vie Di Communicazione. Milano: Franco Angeli.

Arıker, Ç. (2012). Tüketicilerin Restoran Seçiminde Kullandıkları Seçim Kriterleri ile Demografik Özellikleri Arasındaki İlişki, Öneri Dergisi, 10 (38): 11-32.

Auty, S. (1992). Consumer Choice and Segmentation in the Restaurant Industry, The Service Industries Journal, 12 (3): 324-339.

Baker, J., Grewal, D. ve Parasuraman, A. (1994). The Influence of Store Environment on Quality Inferences and Store Image, Journal of the Academy of Marketing Science, 22 (4): 328-339.

Bareham, J. R. (2004). Can Consumers Be Predictable or Are They Unmanageable, International Journal of Contemporary Hospitality Management, 16 (3): 159-165.

Barta, A. (2008). Foreign Tourists' Motivation and Information Source Influencing Their Preference For Eating Out At Ethnic Restaurants in Bangkok, International Journal of Hospitality \& Tourism Administration, 9 (1): 1-17.

Bitner, M. J. (1992). Servicescapes: The Impact of Physical Surroundings on Customers and Employees, Journal of Marketing, 56: 57-71.

Boone, L. E. ve Kurtz, D. L. (2005). Contemporary Marketing. ABD: Thomson Corporation.

Buchtal, K. (2006). Growing up, Restaurants and Institutions, 116 (10): 67-70.

Choi, J., Lee, B., ve Mok, J. (2010). An Experiment on Psychological Gaze Motion: A Reexamination of Item Selection Behavior or Restaurant Customers, Journal of Global Business and Technology, 6 (1): 68-79.

Choi, J. ve Zhao, J. (2010). Factor Influencing South Florida: Is Health Issue One of the Factors Influencing Consumers' Behavior When Selecting a Restaurant?, Journal of Foodservices Business Research, 13 (3): 237-251.

Chow, I. H., Lau, V. P., Lo, T. W., Sha, Z. ve Yun, H. (2007). Service Quality in Restaurant Operations in China: Decision- And Experiential-Oriented Perspectives, International Journal of Hospitality Management, 26 (3): 698-710.

Clark, M. ve Wood, R. C. (1998). Consumer Loyalty in the Restaurant Industry: A Preliminary Exploration of the Issues, International Journal of Contemporary Hospitality Management, 10 (4): 139-144.

Cullen, F. (2004). Factors Influencing Restaurant Selection in Dublin, Journal of Foodservice Business Research, 7 (2): 53-84.

Dash, K. (2005). McDonald's in India. A07-05-0015.Thunderbird. The Garvin School of International Management.

Erik, C. ve Nir, A. (2004). Food in Tourism: Attraction and Impediment, Annals of Tourism Research, 31 (4): 755-778.

Fitzsimmons, J. A. ve Fitzsimmons, M. J. (2000). Services Management, Operations, Strategy and Information Technology. Üçüncü Baskı, Boston: McGraw-Hill. 
Fu, Y. ve Parks, S. C. (2001). The Relationship between Restaurant Service Quality and Consumer Loyalty among the Elderly, Journal of Hospitality and Tourism Research, 25 (3): 320-336.

Gregoire, M. B., Shanklin, C. V., Greathouse, K. R. ve Tripp, C. (1995). Factors Influencing Restaurant Selection by Travelers Who Stop at Visitor Information Centers, Journal of Travel \& Tourism Marketing, 4 (2): 41-50.

Grossbart, S., Hampton, R., Rammohan, B. ve Lapidus, R. S. (2002). Environmental Dispositions and Customer Response to Store Atmospherics, Journal of Business Research, 21 (3): 225-241.

Han, H. ve Ryu, K., (2009). The Roles of The Physical Environment, Price Perception, and Customer Satisfaction in Determining Customer Loyalty in The Family Restaurant Industry, Journal of Hospitality and Tourism Research, 33 (4): 487-510.

Harrington, R. J., Ottenbacher, M. C. ve Kendall, K. W. (2011). Fine-Dining Restaurant Selection: Direct and Moderating Effects of Customer Attributes, Journal of Foodservice Business Research, 14 (3): 272-289.

Heskett, J. R., Sasser, W. E. ve Schlesinger, L. (1997). The Service Profit Chain: How Leading Companies Link Profit and Growth to Loyalty, Satisfaction, and Value. New York: Free Press.

Kara, A., Kaynak, E., ve Küçükemiroğlu, O. (1997). Marketing Strategies For Fast Food Restaurants: A Customer View, British Food Journal, 99 (9): 318-324.

Kim, E. J., ve Geistfeld, L. V. (2003). Consumers' Restaurant Choice Behavior and the Impact of Socio-Economic and Demographic Factors, Journal of Foodservice Business Research, 6 (1): 3-24.

Kim, W. G. ve Moon, Y. J. (2009). Customers' Cognitive, Emotional, and Actionable Response to the Servicescape: A Test of the Moderating Effect of the Restaurant Type, International Journal of Hospitality Management, 28: 144-156.

Kim, Y.-S., Raab, C. ve Bergman, C. (2010). Restaurant Selection Preferences of Mature Tourists in Las Vegas: A Pilot Study, International Journal of Hospitality and Tourism Administration, 11 (2): 157-170.

Kim, Y.S., Bergman, C. ve Raab, C. (2010). Factors That Impact Mature Customer Dining Choices in Las Vegas, Journal of Foodservice Business Research, 13 (3): 178-192.

Kivela, J. (1997). Restaurant Marketing: Selection and Segmentation in Hong Kong, International Journal of Contemporary Hospitality Management, 9 (3): 116-123.

Kivela, J., Inbakaran, R. ve Reece, J. (1999a). Consumer Research in the Restaurant Environment. Part 2: Research Design and Analytical Methods, International Journal of Contemporary Hospitality Management, 11 (6): 269-286.

Kivela, J., Inbakaran, R. ve Reece, J. (1999b). Consumer Research in the Restaurant Environment, Part 1: A Conceptual Model of Dining Satisfaction and Return Patronage, International Journal of Contemporary Hospitality Management, 11 (5): 205-222

Knutson, B., Beck, J. ve Elsworth, J. (2006). The Two Dimensions of Restaurant Selection Important to The Mature Market, Journal of Hospitality Marketing and Management, 14 (3): 35-47.

Kültür ve Turizm Bakanlığı. (2012). İşletme ve Yarım Belgeli Tesis İstatistikleri. http://yigm.kulturturizm.gov.tr/TR,9860/turizm-belgeli-tesisler.html, Erişim tarihi: 5 Mart 2014.
Lahue, P. (2000). The New Mature Market: Senior Market, Restaurant Hospitality, 8 (4): 51-56.

Lin, I. Y. (2004). Evaluating A Servicescape: The Effect of Cognition and Emotion, International Journal of Hospitality Management, 23 (2):163-178.

Lee, S., Koh, Y. ve Kang, K. H. (2011). Moderating Affect of Capital Intensity on the Relationship between Leverage and Financial Distress in the U.S. Restaurant Industry, International Journal of Hospitality Management, 30 (2): 429-438.

Lewis, R.C. (1981). Restaurant Advertising: Appeals and Consumers' Intentions, Journal of Advertising Research, 21 (5): 69-74.

Milliman, R. E. (1982). Using Background Music to Affect the Behavior of Supermarket Shoppers, Journal of Marketing, 46 (3): 86-91.

Myung, M., McCool, A. C. ve Feinstein, A. H. (2008). Understanding Attributes Affecting Meal Choice Decisions in A Bundling Context, International Journal of Hospitality Management, 27 (1): 119-125.

National Restaurant Assosiation. (2011). Statement of Behalf of the National Restaurant Assosiation. http://www.restaurant.org/pdfs/advocacy/20110330_hrc_testimony.pdf, Erişim tarihi: 27 Şubat 2014.

Njite, D., Dunn, G. ve Kim, L.H. (2008). Beyond Good Food: What Other Attributes Influence Consumer Preference and Selection of Fine Dining Restaurants?, Journal of Foodservice Business Research, 11 (2): 237-266.

Nunnally, J. C. (1978). Psychometric Theory. New York: McGrawHill.

Özdemir, B. (2010). Dışarıda Yemek Yeme Olgusu: Kuramsal Bir Model Önerisi, Anatolia: Turizm Araştırmaları Dergisi, 21 (2): 218-232.

Pedraja, M. ve Yague, J. (2001). What Information Do Customers Use When Choosing A Restaurant?, International Journal of Contemporary Hospitality Management, 13 (6): 316-318.

Raab, C., Mayer, K. ve Shoemaker, S. (2009). Price-Sensitivity Measurement: A Tool for Restaurant Menu Pricing, Journal of Hospitality \& Tourism Research, 33 (1): 93-105.

Reynolds, P. (1993). Food and Tourism: Towards an Understanding of Sustainable Culture, Journal of Sustainable Tourism, 1 (1): 48-54.

Rowe, M. (2010). Keep It Casual, Restaurant Hospitality, 94 (3): 24-30.

Sharma, A. ve Stafford, T. F. (2000). The Effect of Retail Atmospherics on Customers' Perceptions of Salespeople and Customer Persuasion: An Empirical Investigation, Journal of Business Research, 49: 183-191.

Sipahi, B., Yurtkoru, E. S. ve Çinko, M. (2008). Sosyal Bilimlerde SPSS le Veri Analizi. Ankara: Seçkin Yayıncilı.

Soriano, D. R. (2001). Customers' Expectations Factors in Restaurants-The Situation in Spain, International Journal of Quality \& Reliability Management, 19 (8/9): 1055-1067.

Sulek, J. M. ve Hensley, R. L. (2004). The Relative Importance of Food, Atmosphere, and Fairness of Wait: The Case of a Full-service Restaurant, Cornell Hotel and Restaurant Administration Quarterly, 45 (3): 235-247.

Tse, A. C. B., Sin L. ve Yim, F. H. K. (2002). How A Crowded Restaurant Affects Consumers' Attribution Behavior, International Journal of Hospitality Management, 21 (4): 449-454. 
Turley, L. W. ve Milliman, R. E. (2000). Atmospheric Effects on Shopping Behavior: A Review of the Experimental Evidence, Journal of Business Research, 49 (2): 193-211.

Türkiye İstatistik Kurumu (2011). Adrese Dayalı Nüfus Kayıt Sistemi, http://rapor.tuik.gov.tr/reports/rwservlet?adnksdb2E $E N V I D=a d n k s d b 2 E n v \mathcal{E} r e p o r t=w a \_t u r k i y e \_i l \_y a s g r . R D F \mathcal{E} p_{-}$ $i l 1=34 \mathcal{E} p \_k o d=2 \mathcal{E} p \_y i l=2011 \mathcal{E} p \_$dil $=1 \mathcal{E}$ desformat $=h t m l$, Erişim tarihi: 5 Mart 2014.

O'Mahony, B. ve Hall, J. (2007). An Exploratory Analysis of the Factors That Influence Food Choice among Young Women, International Journal of Hospitality \& Tourism Administration, 8 (2): 51-72.

Upadhyay, Y., Singh, S. K. ve Thomas, G. (2007). Do People Differ in Their Preferences Regarding Restaurants? An Exploratory Study, The Journal of Business Perspective, 11 (2): 7-22.
Qu, H. (1997). Determinant Factors and Choice Intention for Chinese Restaurant Dining: A Multivariate Approach, Journal of Restaurant and Foodservice Marketing, 2 (2): 35-49.

Yazıcıoğlu, Y. ve Erdoğan, S. (2004). SPSS Uygulamalı Bilimsel Araştırma Yöntemleri. Ankara: Detay Yayıncılık.

Yüksel, A. ve Yüksel, F. (2002). Market Segmentation Based on Tourists' Dining Preferences, Journal of Hospitality $\mathcal{E}$ Tourism Research, 26 (4): 315-331.

Wood, R. (2000). Strategic Questions in Food and Beverage Management. Oxford: Butterworth-Heinemann.

Wootan, M. ve Osborn, M. (2006). Availability of Nutrition Information from Chain Restaurants in the United States, American Journal of Preventative Medicine, 30 (3): 266-268. 